\title{
Cost and Returns from Brinjal in the Study Area
}

\author{
Reena Sahu*, N.K. Raghuwanshi and Ghanshyam Patel \\ Department of Agril. Eco. \& Farm Management, JNKVV, Jabalpur (M.P.), India \\ *Corresponding author
}

\section{Ke y w o r d s \\ Costs, Returns, Cost of cultivation, \\ Profitability, \\ Breakeven, \\ Production, Net \\ income \\ Article Info \\ Accepted: \\ 24 October 2020 \\ Available Online: \\ 10 November 2020}

\section{A B S T R A C T}

\begin{abstract}
The research work entitled "Economics of Brinjal production in Dhamtari Block of Chhattisgarh - An Economic Analysis." was carried out with a view to estimate the costs and returns in brinjal production. Five Villages from Dhamtari block were selected purposively on the basis of area under brinjal crop. After selection of this villages, a list of brinjal growing farmers were prepared and further categorized into three size group on the basis of size of land holding, i.e. small farmer (up to 2.0 ha), medium farmer (2.01 to 4 ha), From each size group 20 farmers were selected randomly. The required data was collected by conducting personal interview of respondents with the help of pre-tested interview schedule. On the primary data pertain to Agricultural year 2015-16, various farm business analysis were carried out to analyze the collected data. The data was analyzed in light of objective using cost of cultivation profitability concept and breakeven production and price. The findings of the study revealed that family size and cultivated area had positive relation with the farm size. The total cost per hectare incurred on brinjal had inverse relation with farm size. The total operational and fixed cost was 56.62 per cent (Rs.49000.48) and 43.37 per cent respectively (Rs.37539.14). Cost concept i.e. A1, A2 B1, $\mathrm{B} 2, \mathrm{C} 1, \mathrm{C} 2$ and $\mathrm{C} 3$ revealed inverse relation with their farm size. The gross income and net income was estimated to Rs 208221 and 113027.23 respectively and benefit cost ratio was found to be 2.18 at aggregate level. Break even yield and prices was estimated to 99.19q/ha and Rs 433.94 respectively.
\end{abstract}

\section{Introduction}

Brinjal (Solanum melongena) is a native of India and perhaps China is a secondary centre of origin. It is one of the important vegetables of tropical countries, particularly India, Bangladesh, Pakistan, China, Japan, Southeast Asia- Indonesia, Thailand and Malaysia and Philippines. There are at least 33 Sanskrit names for eggplant in ancient literature in India. The first record of eggplant in India was during 300 B.C, to 300 A.D. while in China it was described about 500 years ago, perhaps in the 6th century, A.D. It was cultivated in Arica before the middle ages (1).

The vegetable production in India has touched a new height in recent years, placing it as the second largest producer of vegetables in the world, next only to China (Kumar et al., 2005; Kumar et al., 2004). The growing population and the improving economic status in the country have increased vegetables consumption, both across regions and income groups (Kumar and Mathur, 1996; Kumar, 1998) Vegetable cultivation is capital intensive and production risks are very high (Alam, 2001). About 90-98 per cent of the vegetables are sold and used afresh, except some roots and tubers (Subramanian et al., 2000; GOI, 1989) and only 1 per cent of the vegetable output is being processed commercially (Verma et al., 2002). It is an important cash-generating crop to 
small-scale farmers and provides employment in the production and processing industries (2).

Farmers are interested in brinjal production more than any other vegetables for its multiple harvests potential of year round production, which results in high profit per unit area. Besides countrywide problem it helps people in their personal interest to increase input-output ratio, full utilization of farm resources, fulfill the immediate money need being cash crop, less risk, increase in repaying capacity, increase women participation in farming due to its labour intensive nature and finally motivation for the people to adopt the vegetable crop. This study will help us to provide scientific information on the necessary social and psychological factors that would influence the cultivation and large scale brinjal production in the study area (3).

\section{Materials and Methods}

This deal with the materials and research methodology adopted for the present study with respect to the selection of study area, selection of respondents, collection of data and analytical techniques. The research methodology adopted has been described into following subheads:

1. The study area

2. Sampling procedure

3. Collection of data

4. Analytical procedure

\section{Study area}

The present study was confined to Dhamtari block of Chhattisgarh state, which was selected purposively due to highest area for Brinjal cultivation in Chhattisgarh to get more accurate information. From the Dhamtari block, five villages namely, Gagra, Sarangpuri, Kharenga, Bhothipar and Darri were selected randomly for the study.

\section{Sampling procedure}

Selection of respondents (vegetable growers) A list of farmers growing brinjal were prepared in consultation with Rural agriculture extension officer and further categorized into three size group on the basis of their size of holding viz. small (up to 2 ha.), medium (2.01 to 4ha.) and large (above 4 ha.). From each size group 20 brinjal growers were selected randomly the where sample size of 60 respondents.

\section{Collection of data}

\section{Primary data}

The data were collected using survey method. The data on different aspects were collected through pre-tested interview schedule. Each of the selected samples Brinjal growers were approached personally for recording relevant data and following information were respondent.

Information related to cost of different field operations.

(a) Types of labour engaged for different field operations.

(b) Material cost involved.

(c) Returns from main product.

(d) Price of main products

\section{Period of the study}

The primary data were collected in the references related to the agriculture year 2015-16 Rabi season. The data were collected using survey method. The data on different aspects were collected through pre-tested interview schedule. Each of the selected samples Brinjal growers were approached personally for recording relevant data.

\section{Analytical procedure}

The primary data was classified and tabulated in the light of stated objectives of the study and analyzed as per the suitable statistics and economic tools as follows. The estimates of profitability were based on different costs and returns incurred in Brinjal cultivation.

\section{Cost concepts}

The cost of cultivation classified and recommended by "special expert committee on cost estimates, GOI, New Delhi" was used in this study and are given below:

Cost $\mathrm{A} 1=$ All actual expenses incurred in the 
Brinjal production.

Cost A1: it includes:-

i. Value of hired human labour,

ii. Value of hired and owned bullock labour, iii. Value of hired and owned machinery labour, iv. Value of owned and purchased seed,

v. Value of fertilizers, manures and chemical. vi. Value of insecticide and pesticides.

vii. Expenditure on irrigation.

viii. Land revenue and taxes.

ix. Interest paid on crop loan if taken.

$\mathrm{x}$. Depreciation on farm assets excluding land, xi. Interest on working capital,

xii. Miscellaneous expenses.

Cost $\mathrm{A} 2=$ Cost $\mathrm{A} 1+$ rent paid for leased in land .

Cost $\mathrm{B} 1=$ Cost $\mathrm{A} 2+$ interest on value of fixed capital excluding land.

Cost $\mathrm{B} 2=$ Cost $\mathrm{B} 1+$ rental value of owned land.

Cost $\mathrm{C} 1=$ Cost $\mathrm{B} 1+$ imputed value of family labour.

Cost $\mathrm{C} 2=$ Cost $\mathrm{B} 2+$ imputed value of family labour.

Cost $\mathrm{C} 3=\operatorname{Cost} \mathrm{C} 2+10$ per cent of $\cos \mathrm{C} 2$

\section{Evaluation of farm inputs}

Methods followed in evaluating different farm input for the present study are described in the following paragraphs:

\section{Hired human labour}

The farmers normally engage permanent farm labour on the basis of yearly wages and casual labour on daily wages for performing farm operations. The casual labour was evaluated on the basis of actual wages prevailed in the locality. The wages of male and female labour include payment both in cash or kind. The value of kind components given to the labour was calculated at their prevailing market prices.

\section{Family labour}

The family labour cost was evaluated the rate of prevailing wages in the locality for casual hired labour at various stages of operations.

\section{Bullock and machinery labour}

Estimation of bullock and machine labour charges on actual wage prevailed in the locality were considered. For estimation of depreciation, interest on working capital, interest on fixed capital and rental value of owned land, following standard norms were used.

\section{Depreciation on farm assets}

The straight-line method is used for calculating rate of depreciation.

\section{Interest on working capital}

It is worked out @ 4 per cent for half of the duration of the crop.

\section{Interest on fixed capital}

Interest is charged @ 4 per cent annum on the value of implements, machineries, farm building, and irrigation structure and drought animals. It excludes interest on land input, because rental value of owned land is calculated separately.

\section{Rental value of owned land}

It is calculated on the basis of 16.66 per cent (1/6) of the gross income or prevalent rate in the area for the same.

\section{Value of farm produce}

This includes the value of main product and of the crop. The harvest price of the crop was considered for calculating the value of main produce.

\section{Profitability concept}

Gross income $=$ Physical quantity of main product $\times$ price/unit. Quantity of by product $\times$ price/unit.

Net income $=$ Gross income - Total cost .

Benefit - cost ratio $=$ Gross income $/$ Total cost . Cost of production (Rs/qui.) $=$ Total Cost $/$ physical Production of brinjal.

\section{Break -even analysis}

Break-even point indicates a situation where farmers neither earn profit nor in loss. In other 
word break-even points is a point where total cost meet total return plotted on a graph sheet. Breakeven points were obtained as follow:

\section{Break even yield (qt./ha) \\ Break even yield (qt./ha) $=$ \\ $\underline{\text { Total Cost - Value of by product }}$ Output price (Rs/qt.) \\ Break even cost $(\mathrm{qt} . / \mathrm{ha})=$ \\ $\underline{\text { Total Cost - Value of by product }}$ Physical production (qt/ha.)}

\section{Results and Discussion}

This deal with the results of the cross section data collected from the sample holding and analyzed in the light of the objective stated.

\section{Cost of cultivation}

In the farm management studies costs are viewed from different angles for different purposes. Costs of cultivation are used by the Agricultural Cost and Price commission for fixation of support price of agricultural commodities. Besides this, they are also useful in farm planning and policy making. Therefore, operational costs of brinjal were work out to operate agriculture in an over under study and presented in table.

The farmers cultivated brinjal crop in 15.33 per cent of the gross cropped area of the sample farm. It is observed from the Table that the total cost incurred in cultivation of brinjal at the overall farm was Rs. 95193.76 per hectare which was higher in large farm (Rs. 108702.07/ha) and lowest in small farm (Rs. 80834.68/ha). This revealed inverse relation with the farm size due to scale economies. The operational cost was 56.63 per cent (Rs. 49000.48) of the total cost and the fixed cost was Rs. 37539.14, accounted for around 43.37 per cent of the total cost.

The labour cost on an average accounted to be 28.05 per cent of the total cost which varied from 27.12 per cent in large farm to 29.33 per cent in medium farm. The variation in total labour requirement among different size farms is due to difference in the style of operational practices.

Among material cost, seed alone contributed about 1.55 per cent at overall level of the total cost lowest (Rs. 1282.95/ha) being in medium farm and highest being in large farm (Rs. 1422.72/ha). The expenditure on Manure and fertilizer together accountant 13.47 per cent of the total cost on sample farm which varied between 12.52 to14.16 per cent for different size groups. Irrigation cost on an average accounted to be 2.90 per cent of the total cost. Plant protection chemical cost was around 8.69 per cent of the total cost. Interest on working capital was to the extent of 1.93 per cent of total cost on various sizes of farms. Rental value of land fixed items shared 40.10 per cent of the total cost which revealed inverse relation with farm size. The yield of main product per hectare was found to be 219.18/ha at overall level, lowest being in small farm $(189.8 \mathrm{q} / \mathrm{ha})$ and highest being in large farm (250.14qt/ha), indicating the intensive cultivation of brinjal by sample farmers in the study area.

\section{Cost concept}

Almost every day in farm organization and operation cost consideration enters. It is an important tool for measuring farm business activities. The farm management specialists have specified cost of cultivation into cost A1, A2, B1, B2 Cost C1, C2 \& C3. These cost concepts have already been taken up in the methodology chapter. In this section efforts have been made to discuss cost of cultivation according to various costs concepts.

The table clearly shows that on an average total cost of (cost c3) Rs. 95193.76 per hectare was required to produce this crop of an overall level which 53.45 per cent comprised for the variable cost commonly known as cost A1and A2 After adding interest on fixed capital to cost $\mathrm{A} 1$, the cost went up to 53.58 per cent as cost B1 and when imputed value of land was further added it increased up to 93.68 per cent. Thus cost the C2 and 10 per cent cost of the cost $\mathrm{C} 2$ when added in this cost, it form total cost or cost C3. Table further inferred that cost $\mathrm{A} 1$ to Cost $\mathrm{C} 3$ increases with the increase in size of holding. 
Table.1 Selection of respondents according to farm size

\begin{tabular}{|c|c|c|c|}
\hline Size group & Total No. of Brinjal growers & No. of farmers selected & Percentage of farmers selected \\
\hline Small & 60 & 20 & 33.33 \\
\hline Medium & 52 & 20 & 38.46 \\
\hline Large & 30 & 20 & 66.66 \\
\hline Total & 142 & 60 & 42.25 \\
\hline
\end{tabular}

Table. 2 Cost of cultivation of brinjal on sample farm (Rs/ha)

\begin{tabular}{|c|c|c|c|c|c|}
\hline \multirow{2}{*}{\multicolumn{2}{|c|}{ Particulars }} & \multicolumn{4}{|c|}{ Size group } \\
\hline & & Small & Medium & Large & Overall \\
\hline \multicolumn{6}{|c|}{ 1. Operational cost } \\
\hline \multicolumn{6}{|c|}{ A. Labour cost } \\
\hline \multirow[t]{2}{*}{ i.Human labour } & Family & $\begin{array}{c}5585 \\
(7.60)\end{array}$ & $\begin{array}{c}6441.71 \\
(7.37)\end{array}$ & $\begin{array}{c}4372 \\
(4.42)\end{array}$ & $\begin{array}{c}5466.23 \\
(6.31)\end{array}$ \\
\hline & Hired & $\begin{array}{c}12540.30 \\
(17.06)\end{array}$ & $\begin{array}{c}16673.22 \\
(19.09)\end{array}$ & $\begin{array}{c}18887.17 \\
(19.11)\end{array}$ & $\begin{array}{c}16033.56 \\
(18.52)\end{array}$ \\
\hline $\begin{array}{l}\text { ii. Machine } \\
\text { labour }\end{array}$ & $\begin{array}{l}\text { Owned + } \\
\text { Hired }\end{array}$ & $\begin{array}{c}2300 \\
(3.12)\end{array}$ & $\begin{array}{l}2500 \\
(2.86)\end{array}$ & $\begin{array}{l}3545 \\
(3.58)\end{array}$ & $\begin{array}{c}2781.66 \\
(3.21)\end{array}$ \\
\hline \multicolumn{2}{|l|}{ Sub Total } & $\begin{array}{l}20425.30 \\
(27.79)\end{array}$ & $\begin{array}{l}25614.93 \\
(29.33)\end{array}$ & $\begin{array}{c}26804.17 \\
(27.12)\end{array}$ & $\begin{array}{c}24281.46 \\
(28.05)\end{array}$ \\
\hline \multicolumn{6}{|l|}{ B. Material cost } \\
\hline \multicolumn{2}{|l|}{ i. Seed } & $\begin{array}{c}1322.70 \\
(1.79)\end{array}$ & $\begin{array}{c}1282.95 \\
(1.46)\end{array}$ & $\begin{array}{c}1422.72 \\
(1.43)\end{array}$ & $\begin{array}{c}1342.79 \\
(1.55)\end{array}$ \\
\hline \multicolumn{2}{|c|}{ ii. fertilizer \& manure } & $10060.41(13.69)$ & $\begin{array}{c}10931.96 \\
(12.52)\end{array}$ & $\begin{array}{c}13995.64 \\
(14.16)\end{array}$ & $\begin{array}{c}11662.67 \\
(13.47)\end{array}$ \\
\hline \multicolumn{2}{|c|}{ iii. Plant protection } & $\begin{array}{l}5536 \\
(7.53)\end{array}$ & $\begin{array}{c}7794 \\
(8.92)\end{array}$ & $\begin{array}{l}9240.10 \\
(9.35)\end{array}$ & $\begin{array}{l}7523.36 \\
(8.69)\end{array}$ \\
\hline \multicolumn{2}{|c|}{ iv. Irrigation charges } & $\begin{array}{l}2662 \\
(3.62)\end{array}$ & $2349.09(2.69)$ & $\begin{array}{c}2536.31 \\
(2.56)\end{array}$ & $\begin{array}{c}2515.80 \\
(2.90)\end{array}$ \\
\hline \multicolumn{2}{|c|}{ Total material cost } & $19581.11(26.64)$ & $\begin{array}{l}22358 \\
(25.60)\end{array}$ & $\begin{array}{c}27194.77 \\
(27.51)\end{array}$ & $\begin{array}{c}23044.62 \\
(26.62)\end{array}$ \\
\hline \multicolumn{2}{|c|}{$\begin{array}{l}\text { Interest on } \\
\text { working capital@ 4\% }\end{array}$} & $\begin{array}{c}1376.85 \\
(1.87)\end{array}$ & $1661.24(1.90)$ & $\begin{array}{c}1985.07 \\
(2.00)\end{array}$ & $\begin{array}{c}1674.38 \\
(1.93)\end{array}$ \\
\hline \multicolumn{2}{|c|}{ Total operational cost $(\mathrm{A}+\mathrm{B})$} & $\begin{array}{l}41383.26 \\
(56.30)\end{array}$ & $\begin{array}{l}49634.17 \\
(56.84)\end{array}$ & $\begin{array}{l}55984.01 \\
(56.65)\end{array}$ & $\begin{array}{l}49000.48 \\
(56.62)\end{array}$ \\
\hline \multicolumn{2}{|c|}{ A. Rental value of land } & $\begin{array}{c}30051.66 \\
(40.89)\end{array}$ & $\begin{array}{c}34453.33 \\
(39.45)\end{array}$ & $\begin{array}{l}39605.5 \\
(40.07)\end{array}$ & $\begin{array}{c}34703.49 \\
(40.10)\end{array}$ \\
\hline \multicolumn{2}{|l|}{ B. Depreciation } & $\begin{array}{c}1960.78 \\
(1.87)\end{array}$ & $\begin{array}{c}3089.73 \\
(3.53)\end{array}$ & $\begin{array}{l}3094.72 \\
(3.13)\end{array}$ & $\begin{array}{c}2715.07 \\
(3.13)\end{array}$ \\
\hline \multicolumn{2}{|l|}{ C. Revenue/tax } & $\begin{array}{l}12.00 \\
(0.014)\end{array}$ & $\begin{array}{l}12.00 \\
(0.012)\end{array}$ & $\begin{array}{c}12.00 \\
(0.011)\end{array}$ & $\begin{array}{c}12 \\
(0.013)\end{array}$ \\
\hline \multicolumn{2}{|c|}{$\begin{array}{l}\text { D. Interest on fixed } \\
\text { cost@ } 4 \%\end{array}$} & $\begin{array}{l}78.43 \\
(0.10)\end{array}$ & $\begin{array}{l}123.58 \\
(0.14)\end{array}$ & $\begin{array}{l}123.7 \\
(0.12)\end{array}$ & $\begin{array}{l}108.60 \\
(0.12)\end{array}$ \\
\hline \multicolumn{2}{|l|}{ Total fixed cost } & $\begin{array}{c}32102.87 \\
(43.68)\end{array}$ & $\begin{array}{c}37678.64 \\
(43.15)\end{array}$ & $\begin{array}{c}42835.92 \\
(43.34)\end{array}$ & $\begin{array}{c}37539.14 \\
(43.37)\end{array}$ \\
\hline \multicolumn{2}{|c|}{$\begin{array}{l}\text { Total cost (Operational } \\
\text { cost + Fixed cost) }\end{array}$} & $\begin{array}{c}73486.08 \\
(100)\end{array}$ & $\begin{array}{c}87313.23 \\
(100)\end{array}$ & $\begin{array}{c}98820.07 \\
(100)\end{array}$ & $\begin{array}{c}86539.79 \\
(100)\end{array}$ \\
\hline
\end{tabular}

(Figures in brackets indicate percentage to the total) 
Table.3 Cost of cultivation of Brinjal according to cost concept on sample farms

\begin{tabular}{|l|l|l|l|l|l|}
\hline \multirow{2}{*}{ S.No. } & \multirow{2}{*}{ Cost } & \multicolumn{4}{|c|}{ Size group } \\
\cline { 3 - 6 } & & Small & Medium & Large & Overall \\
\hline $\mathbf{1}$ & Cost $\mathrm{A}_{1} \& \mathrm{~A}_{2}$ & 37771.04 & 46294.19 & 54718.73 & $46261.32(53.45)$ \\
\hline $\mathbf{2}$ & Cost $\mathrm{B}_{1}$ & 37849.47 & 46417.77 & 54842.43 & $46369.89(53.58)$ \\
\hline $\mathbf{3}$ & Cost $\mathrm{B}_{2}$ & 67901.13 & 80871.10 & 94447.93 & $81073.38(93.68)$ \\
\hline $\mathbf{4}$ & Cost $\mathrm{C}_{1}$ & 43434.42 & 52859.9 & 59214.40 & $51836.23(59.89)$ \\
\hline $\mathbf{5}$ & Cost $\mathrm{C}_{2}$ & 73486.08 & 87313.2 & 98820.2 & $86539.79(100)$ \\
\hline $\mathbf{6}$ & Cost $\mathrm{C}_{3}$ & 80834.68 & 96044.55 & 108702.07 & $95193.76(100)$ \\
\hline
\end{tabular}

(Figures in brackets indicate percentage to the total cost)

Table.4 Profitability of brinjal production on sample farm

\begin{tabular}{|c|c|c|c|c|c|}
\hline \multirow{2}{*}{ S.No. } & \multirow{2}{*}{ Economic parameter } & \multicolumn{4}{|c|}{ Size group } \\
\cline { 3 - 6 } & & Small & Medium & Large & Overall \\
\hline $\mathbf{1}$ & Total operational cost & 41383.26 & 49634.17 & 55984.01 & 49000.48 \\
\hline $\mathbf{2}$ & Total cost & 80834.688 & 96044.55 & 108702.07 & 95193.76 \\
\hline $\mathbf{3}$ & Yield(q/ha) & 189.8 & 217.6 & 250.14 & 219.18 \\
\hline $\mathbf{4}$ & Gross income (Rs/ha) & 180310 & 206720 & 237633 & 208221 \\
\hline $\mathbf{5}$ & Net income & 99475.32 & 110675.45 & 128930.93 & 113027.23 \\
\hline $\mathbf{6}$ & BC Ratio & $1: 2.23$ & $1: 2.15$ & $1: 2.18$ & $1: 2.18$ \\
\hline $\mathbf{7}$ & Cost of production (Rs/q) & 425.89 & 441.38 & 434.56 & 433.94 \\
\hline
\end{tabular}

Table.5 Break even yield (q/ha) and price (Rs/qt) of brinjal on sample farm

\begin{tabular}{|c|c|c|c|}
\hline Size group & Actual yield & Break even yield & Breakeven price \\
\hline Small & 189.8 & 82.08 & 425.89 \\
\hline Medium & 217.6 & 101.09 & 441.38 \\
\hline Large & 250.14 & 114.42 & 434.56 \\
\hline Over all & 219.18 & 99.19 & 433.94 \\
\hline
\end{tabular}

\section{Profitability concepts}

In any field of business activity profit is the prime consideration. Thus, how much a farmer earns as net income and family labour income as a producing unit and how much satisfaction he and his family derives as a consuming unit are the major deciding factor in organization and operation of farm. Hence, in this section efforts have been made to estimate the gross income, total operational cost and total cost, net income, Benefit cost ratio, cost of production of brinjal a sample farm.

From the table it is clear that the total cost from brinjal were Rs. 80834.68, Rs. 96044.55 and Rs.
108702.07 in case of small, medium and large farm with an average of Rs. 95193.76 on sample farm. Thus, total cost incurred in brinjal production increase with an increase in farm size. When physical output obtained from brinjal are converted into monetary terms Benefit cost ratio in other words can be termed as the return per rupee of investment. The Benefit cost ratio was more favorable to small farm (2.23), followed by medium farm (2.15) and large farm (2.18). Therefore, it could be concluded that there is increase in the ratio of benefit cost ratio as the size of land holding increase.

At overall level the Net income per hectare was found to be Rs. 113027.23/ha, lowest being small 
farm (Rs.99475.32/ha) and highest being in large farm (Rs.128930.93/ha) and (Rs.110675.45/ha) in being of medium farm. The overall per rupee investment (B : C ratio) was found to be 2.18 at overall level lowest being in medium (2.15) and highest being in small (2.23) farm size. The cost of production per quintal was found to be 425.89 , 441.40 and 434.56 in small, medium and large size found with Rs.433.94/q of overall level.

\section{Break-even analysis}

Break even analysis is carried out to arrive at the minimum level at which optimum conditions of cost and returns is equated that is no profit no loss point obtained where the return is equal to total cost.

The break even yield as shows in tale 5.12 implies that with the given cost and physical output, brinjal would remain proposition of no profit and no loss within the yield range of 82.08 to 189.8 qt/ha on small farm, 101.09 to $217.6 \mathrm{qt} /$ ha medium farm and 114.42 to $250.14 \mathrm{qt} / \mathrm{ha}$ on large farm, thus the existing cost of production and physical output of crop yielded sufficient profit to the sample farms.

The break-even price per quintal was estimated to be Rs. 433.94 on an average at overall level which varied between Rs. 425.89/qt on small farm to Rs 441.38 on medium farm and the selling price as per the market was Rs 950/qt of brinjal. Thus, the farmer had sufficient incremental profit in the study area.

In conclusions, total cost per hectare incurred in brinjal production on sample farm was Rs. 86539.79 the proportion of operational cost and fixed cost to total cost on sample farm was 56.62 and 43.37 of the total cost. Cost of cultivation according to various cost concepts (Cost A1 to Cost C3) in different size of farms increased as the farm size increases. Storage facilities are inadequate at present. Hence, it is recommended that storage facility is required to be made available to solve storage related problems.

\section{References}

1. Akter S, Islam MS. 2011. An economic analysis of winter vegetable production in some selected area of Narsingdi district. J. Bangladesh Agri. Univ. 9(2): 241-246.

2. Baba S.H., Wani M.H., Wani S.A. and Yousuf S.2010. "Marketed Surplus and Price Spread of Vegetables in Kashmir Valley". Agricultural Economics Research Review. Vol. 23 January-June 2010 pp 115127.

3. Chowdhuri NY and Haque S. 2014. Profitability analysis of winter vegetables production in a selected area of Narshingdi district in Bangladesh. Progressive Agriculture 25: 47-53.

4. Chandrashekhar SK. 2007. Analysis of onion production and marketing behavior of farmers in Gadag district, Karnataka. M. Sc. (Agri.) Thesis, Univ. Agric Sci., Dharwad, Karnataka (India).

5. Dinkar S. 2014. An Economic Analysis of Production And Marketing Of Major Vegetables In Korba District. Thesis Submitted to department of Agricultural and Natural Resource Economic, IGKV Raipur, Chhattisgarh.

6. Kerutagi MG and Kotikal YK. 2000. Costs and returns from brinjal production in Gokak taluk of Karnataka, Journal Agriculture Science 13(2): 500-502.

7. Kiruthika N. 2013. "The Economics of Production of Turmeric In India: A Case OF Erode District Of Tamil Nadu". Journal of Innovative Research and Solutions 1(1): 2330.

8. Lokesh GB, Shilpa G and MG, Handrakanth. 2005. An Economic Analysis of Tomato Production, Marketing and Processing in Karnataka. Department of Horticulture, Karnataka. Agricultural Marketing journal, 47(4):15-21.

9. Meshram RR., Shende NV, Kathale SD. 2015. Cost Benefit Analysis and Marketing of Brinjal Vegetable in Bhandara District. American International Journal of Research in Formal, Applied \& Natural Sciences, P: ISSN No.0976-8602 RNI No. UPENG/2012/42622, 4(4): 85-92.

10. Mhatare Suhasini J. 2014. Economic analysis of production and marketing of Brinjal in South Gujarat. Gricultural Economics Dept., N.M. college of 
agriculture, Navasari agricultural university, Navsari.

11. Nandeshwar NS and Jagannath 2013. Economics of Production and Marketing of vegetables in Akola district. Global journal of Biology, Agric. \& Health Sci. 2(2):78-82.

12. Noonari S, Memon IN, Solangi SU, Laghari MA, Wagan SA, Sethar A, Kalwar GY and Korejo A. 2015. Research on Humanities and Social Sciences. 5(7):158-170.

13. Ramya SI. 2009. Production and Marketing of Major Vegetable in Bilaspur District. Thesis Submitted to department of Agricultural and Natural Resource Economics, IGKV Raipur, Chhattisgarh.
14. Saraswat Vidhya and Sharma S. 2014. Economics of Brinjal Production in South Gujarat. Economic Affairs 59(2):231-241.

15. Singh AK and Banafar KNS. 2006. Economic Analysis of Production and Marketing of Cauliflower in Durg District of Chhattisgarh State. Agricultural Marketing, 41(1): 37-39.

16. Verma PK. 2006. Production and Marketing of Summer Vegetables and Fruits Crops in Mahanadi River Bed of Raipur District. Thesis submitted to Department of Agriculture and Natural Resource Economics, IGKV, Raipur, Chhattisgarh.

\section{How to cite this article:}

Reena Sahu, N.K. Raghuwanshi and Ghanshyam Patel. 2020. Cost and Returns from Brinjal in the Study Area. Int.J.Curr.Microbiol.App.Sci. 9(11): 3445-3452.

doi: https://doi.org/10.20546/ijcmas.2020.911.411 